\title{
Implementasi Teknik Pengelolaan Diri Untuk Meningkatkan Kedisiplinan Siswa
}

\author{
Hasbahuddin $^{1^{*}}$, Rosmawati $^{2}$ \\ ${ }^{1}$ Bimbingan Konseling, STKIP Andi Matappa, Indonesia \\ ${ }^{2}$ Bimbingan Konseling, STKIP Andi Matappa, Indonesia \\ *)Corresponding author, E-mail: hasba konseling@yahoo.com
}

\begin{abstract}
Abstrak. Permasalahan utama yang terjadi di sekolah adalah rendahnya penerapan disiplin belajar bagi siswa. Pengelolaan diri merupakan prosedur dimana individu mengatur dirinya sendiri pada teknik ini individu terlibat pada beberapa atau keseluruhan komponen dasar. Tujuan penelitian ini yakni mengimplementasikan teknik pengelolaan diri untuk meningkatkan kedisiplinan siswa di Kabupaten Pangkep. Model rancangan penelitian ini adalah one-group pretestposttest design. Instrumen yang digunakan dalam penelitian ini adalah angket kedisiplinan siswa dan skenario pelaksanaan teknik pengelolaan diri. Sampel dalam penelitian ini sebanyak 30 orang siswa. Teknik analisis data yang digunakan adalah statistik deskriftif dan statistik inferensial dengan menggunakan uji t sebagai uji hipotesis. Hasil penelitian menunjukkan bahwa gambaran tingkat kedisiplinan siswa sebelum diberikan perlakuan berupa teknik pengelolaan diri berada pada kategori rendah. Selanjutnya tingkat kedisiplinan siswa setelah diberikan perlakuan berupa teknik pengelolaan diri berada pada kategori tinggi. Selain itu berdasarkan hasil uji hipotesis penelitian dapat simpulkan bahwa ada pengaruh strategi implementasi teknik pengelolaan diri untuk meningkatkan kedisiplinan siswa di SMA Negeri 3 Pangkep, artinya melalui implementasi teknik pengelolaan diri, maka kedisiplinan siswa meningkat.
\end{abstract}

Kata Kunci: Pengelolaan diri; kedisiplinan

\begin{abstract}
The main problem that occurs in schools is the low application of learning discipline for students. Self-management is a procedure where the individual organizes himself in this technique the individual is involved in some or all of the basic components. The purpose of this study is to implement self-management techniques to improve student discipline in Pangkep Regency. This research design model is a one-group pretest-posttest design. The instrument used in this study was a student discipline questionnaire and self-management scenario implementation techniques. The sample in this study were 30 students. The data analysis technique used is descriptive statistics and inferential statistics using the $t$ test as a hypothesis test. The results showed that the level of student discipline before being treated in the form of self-management techniques was in the low category. Furthermore, the level of student discipline after being given treatment in the form of selfmanagement techniques is in the high category. In addition, based on the results of the research hypothesis test, it can be concluded that there is an influence of the implementation strategy of self-management techniques to improve student discipline in SMA 3 Pangkep, meaning that through the implementation of self-management techniques, student discipline will increase.
\end{abstract}

Keywords: Self-management; discipline

This is an open access article distributed under the Creative Commons Attribution License, which permits unrestricted use, distribution, and reproduction in any medium, provided the original work is properly cited. (C2019 by author.

\section{Pendahuluan}

Sesorang siswa yang ingin sukses dalam mengikuti suatu jenjang pendidikan tidak cukup hanya dengan belajar, tetapi harus dibarengi dengan yang namanya disiplin agar tercipta suatu kondisi yang terarah dan mencapai prestasi sesuai dengan yang diharapkan oleh guru dan orang 
tua. Disiplin adalah tindakan yang menunjukan perilaku tertib dan patuh pada berbagai ketentuan dan peraturan, (Wibowo, 2012).

Disiplin Belajar adalah kesadaran diri untuk mengendalikan atau mengontrol dirinya untuk sungguh-sungguh belajar. Kedisiplinan penting untuk diterapkan dalam kehidupan sehari-hari, tapi sering menjadi masalah di sekolah karena hampir setiap hari ada saja siswa yang melanggar disiplin, (Fiana, 2013). Seluruh proses pendidikan di sekolah, kegiatan belajar merupakan kegiatan yang paling pokok, ini berarti bahwa berhasil-tidaknya pencapaian tujuan pendidikan banyak bergantung pada proses belajar yang dialami siswa, (Slameto, 2010).

Disiplin adalah serangkaian perilaku yang menunjukkan nilai-nilai ketaatan, kepatuhan, kesetiaan, keteraturan atau ketertiban yang muncul dari dalam diri individu, (Elly, 2016). Kedisiplinan di sekolah penting untuk melatih siswa menjadi pribadi yang bertanggung jawab, mandiri, dan mampu mengatur dan mengontrol setiap perilaku. Fungsi disiplin adalah menata kehidupan bersama, membangun kepribadian, melatih kepribadian yang baik, pemaksaan, hukuman dan menciptakan lingkungan yang kondusif. Tujuan disiplin belajar yang adalah untuk menolong peserta didik memperoleh keseimbangan antara kebutuhannya untuk berdikari dan penghargaan terhadap orang lain.

Kedisiplinan siswa dalam penelitian ini adalah sikap atau tingkah laku siswa yang taat dan patuh untuk dapat menjalankan kewajibannya untuk belajar, baik belajar di sekolah maupun belajar di rumah serta bertingkahlaku sesuai dengan norma dan tata tertib yang berlaku. Adapun ciri-ciri disiplin dalam penelitian ini adalah sebagai berikut: 1) Taat terhadap peraturan dan tata tertib sekolah; 2) Taat terhadap kegiatan belajar di sekolah; 3) Taat terhadap norma - norma yang berlaku; 4) Taat dalam mengerjakan tugas-tugas pelajaran; dan 5) Bertanggung jawab terhadap apa yang diucapkan dan dilakukan

Faktor penyebab peserta didik tidak disiplin belajar dipengaruhi oleh beberapa hal, yaitu dorongan dari dalam diri peserta didik (intern) seperti pengetahuan, kesadaran, ketaatan, keinginan berprestasi, dan latihan berdisiplin. Adapun dorongan dari luar peserta didik (ekstern) mencakup lingkungan, alat pendidikan, teman, saudara, kebiasaan dan pembinaan dari rumah, sarana yang menunjang, pengawasan, hukuman, nasihat, dan sebagainya (Haryono, 2016).

Untuk mengatasi masalah disiplin belajar, maka perlu diberikan suatu teknik untuk membimbing peserta didik dalam upaya meningkatkan disiplin belajar dan secara sadar berkeinginan untuk mengubah perilakunya sendiri, khususnya disiplin belajar yang rendah. Diharapkan dengan teknik pengubahan perilaku dapat mengganti perilaku peserta didik yang benar guna meningkatkan disiplin belajar. Teknik atau strategi yang berfungsi untuk mengubah perilaku adalah dengan pendekatan behavior. Salah satunya adalah dengan self-management (pengelolaan diri).

Pengelolaan diri menurut adalah prosedur dimana individu mengatur dirinya sendiri pada teknik ini individu terlibat pada beberapa atau keseluruhan komponen dasar yaitu: menentukan perilaku sasaran, memonitor perilaku tersebut, memilih perilaku tersebut, memilih prosedur yang akan diterapkan, melaksanakan prosedur tersebut dan mengevaluasi efektifitas prosedur tersebut, (Komalasari, 2011).

Strategi self-management (pengelolaan diri) adalah prosedur pengaturan perilaku oleh individu sendiri, pada strategi ini, individu terlibat pada beberapa atau keseluruhan komponen dasar yaitu: menentukan perilaku sasaran, memonitor perilaku tersebut, memilih prosedur yang akan diterapkan, melaksanakan prosedur tersebut, dan mengevaluasi efektifi tas prosedur tersebut, (Komalasari, 2011).

Teknik pengelolaan diri adalah teknik menata perilaku individu yang bertujuan untuk mengarahkan dan mengelola dirinya agar dapat mencapai kemandirian dan hidupnya berjalan dengan produktif, (Sa'diyah, 2016). Tujuan self-management dapat untuk mengurangi perilaku yang tidak pantas dan mengganggu (perilaku yang mengganggu, tidak menyelesaikan tugas sekolah dan tugas-tugas secara mandiri dan efi sien, dll.) dan meningkatkan sosial, adaptif dan kemampuan bahasa/ komunikasi.

Kelebihan strategi "self-management" yaitu penggunaan strategi pengelolaan diri dapat meningkatkan pengamatan seseorang dalam mengontrol lingkungannya serta dapat menurunkan ketergantungan seseorang pada konselor atau orang lain, pendekatan yang murah dan praktis, 
mudah digunakan, dan menambah proses belajar secara umum dalam berhubungan dengan lingkungan baik pada situasi bermasalah atau tidak.

Terdapat tiga strategi atau prosedur SM, yaitu (1) self monitoring, (2) stimulus-control, dan (3) self-reward. Pendapat tersebut dapat dimaknai bahwa untuk membentuk dan merubah perilaku disiplin terhadap tata tertib sekolah yang diinginkan dapat dilakukan melalui tiga tahap, (Nursalim, 2013:150). Tahap yang pertama yaitu self-monitoring yaitu individu memantau dan mengamati setiap tindakan dan perilakunya sendiri. Pada tahap selanjutnya yaitu stimulus-control yaitu individu mulai menata kembali pola berpikir, pola perilakunya, dan emosinya dengan tujuan untuk mengurangi perilaku tidak disiplin terhadap tata tertib sekolah. Tahap terakhir yaitu selfreward yaitu individu memperkuat perilakunya melalui konsekuensi yang dihasilkannya sendiri. Jika konseli dapat berperilaku disiplin terhadap tata tertib sekolah maka konseli tersebut akan memperoleh penghargaan atau hadiah dan jika konseli berperilaku tidak disiplin terhadap tata tertib sekolah maka konseli tersebut tidak akan memperoleh hadiah.

Pendapat di atas sejalan dengan hasil penelitian sebelumnya bahwa kedisiplinan belajar dapat ditingkatkan melalui konseling kelompok dengan strategi self-management. Hal ini dibuktikan adanya uji $\mathrm{n}$ sampel bebas Kruskal-Wallis pengaruh kedisiplinan belajar diantara ketiga kelompok jika dibandingkan secara bersama-sama. Sehingga dapat disimpulkan bahwa kedisiplinan belajar meningkat disebabkan oleh pemberian perlakuan konseling kelompok dengan strategi self-management dan bukan disebabkan oleh faktor lainnya, (Isnaini \& Taupik, 2015).

Selanjutnya tingkat kedisiplinan belajar siswa sebelum diberikan teknik self management berada pada kategori rendah dan tingkat kedisiplinan belajar siswa setelah diberikan teknik self management mengalami peningkatan menjadi kategori sedang sampai tinggi. Terdapat peningkatan yang signifikan pada tingkat kedisiplinan belajar siswa setelah diberikan teknik self management, (Fajriani, 2016).

Selain itu, penerapan konseling kelompok dengan strategi pengelolaan diri dapat meningkatkan disiplin belajar siswa kelas IV SDN 1 Triwarno artinya penerapan konseling kelompok dengan strategi pengelolaan diri cocok jika digunakan untuk meningkatkan disiplin beajar siswa, (Nuryasih, 2017).

Kendala pengelolaan diri yakni kurangnya motivasi dan komitmen pada individu, target perilaku seringkali bersifat pribadi dan persepsinya sangat subjektif terkadang sulit didiskripsikan sehingga konselor sulit untuk menentukan cara memonitor dan mengevaluasi, lingkungan sekitar dan keadaan diri individu di masa mendatang sering tidak dapat diatur dan diprediksikan dan bersifat kompleks. Individu bersifat independen, konselor memaksakan program pada klien, tidak ada dukungan dari lingkungan.

Berdasarkan pengamatan peneliti terhadap siswa di SMA Negeri 3 Pangkep, bahwa permasalahan utama yang terjadi di sekolah adalah rendahnya penerapan disiplin belajar bagi siswa. Contoh kasus; pada saat jam pelajaran dimulai siswa-siswa masih berkeliaran di luar kelas, siswa tidak tepat waktu memasukkan tugas yang diberikan oleh guru, siswa membuat keributan pada saat jam pelajaran dimulai. Permasalahan tersebut akan berdampak negatif terhadap hasil belajar, khususnya pada tahap akhir evaluasi kenaikan kelas. Adanya pelanggaran yang terjadi disebabkan oleh kurang pahamnya siswa tentang pentingnya menerapkan disiplin pada diri di lingkungan sekolah. Berdasarkan uraian di atas, maka artikel ini berjudul "Implementasi Teknik Pengelolaan Diri Untuk Meningkatkan Kedisiplinan Siswa Di Kabupaten Pangkep".

\section{Metode}

Lokasi penelitian yakni di SMA Negeri 3 Pangkep Kabupaten Pangkep dan subjek penelitian yakni siswa yang berjumlah 30 orang sebagai sampel penelitian. Penelitian ini dimaksudkan untuk mengkaji dua variabel, yaitu: bimbingan keterampilan sosial sebagai variabel bebas atau yang mempengaruhi (independen), dan perilaku agresif siswa sebagai variabel terikat atau yang dipengaruhi (dependen).

Guna memperoleh batasan tentang kedua variabel, maka perlu dibuat definisi operasional dari variabel tersebut, yaitu: 1) Teknik pengelolaan diri (Self-Management) merupakan suatu teknik dalam konseling kelompok melalui prosedur pengubahan tingkah laku klien yang menunjuk pada kemampuan individu untuk memonitor diri, mengarahkan perilaku sendiri dengan cara 
memodifikasi aspek-aspek lingkungan atau menciptakan konsekuensi-konsekuensi dan memberikan hadiah pada diri sendiri bila berperilaku sesuai yang diharapkan. Adapun langkahlangkah teknik pengelolaan diri yang dimaksud yakni 1) self monitoring, 2) stimulus control, dan 3) self reward. 2) Kedisiplinan siswa dalam penelitian ini adalah sikap atau tingkah laku siswa yang taat dan patuh untuk dapat menjalankan kewajibannya untuk belajar, baik belajar di sekolah maupun belajar di rumah serta bertingkahlaku sesuai dengan norma dan tata tertib yang berlaku. Adapun ciri-ciri disiplin dalam penelitian ini adalah sebagai berikut: 1) Taat terhadap peraturan dan tata tertib sekolah; 2) Taat terhadap kegiatan belajar di sekolah; 3) Taat terhadap norma norma yang berlaku; 4) Taat dalam mengerjakan tugas-tugas pelajaran; dan 5) Bertanggung jawab terhadap apa yang diucapkan dan dilakukan.

Penelitian ini menggunakan pendekatan kuantitatif dengan jenis penelitian eksperimen yang akan mengkaji tentang strategi implementasi bimbingan keterampilan sosial untuk mengurangi perilaku agresif siswa di Kabupaten Pangkep. Desain penelitian yang digunakan adalah one-group pretest-posttest. one-group pretest-posttest design.

Adapun teknik pengumpulan data yang digunakan dalam penelitian adalah angket tingkat kedisiplinan siswa merupakan teknik pengumpulan data yang dilakukan dengan cara memberi seperangkat pernyataan tertulis kepada responden untuk dijawab. Angket tersebut diberikan kepada subjek penelitian untuk memperoleh gambaran tingkat kedisiplinan siswa sebelum (Preetest) diberikan perlakuan berupa pemberian teknik pengelolaan diri dan sesudah (Posttest) diberikan perlakuan berupa pemberian teknik pengelolaan diri. Sebelum angket digunakan untuk penelitian lapangan, terlebih dahulu divalidasi oleh validator ahli, kemudian diuji coba lapangan dan kemudian dilakukan uji validitas dan reliabilitas angket penelitian.

Teknik analisis data yang digunakan adalah teknik analisis statistik deskriptif yaitu: 1) Analisis Statistik Deskriptif. Analisis statistik deskriptif dimaksudkan untuk memperoleh gambaran tingkat kedisiplinan siswa di SMA Negeri 3 Pangkep Kabupaten Pangkep, deskripsi tersebut diperoleh dari hasil angket pre-test dan post-test. 2) Uji Hipotesis. Hipotesis yang telah dirumuskan akan diuji dengan statistik parametrik dengan menggunakan $t$-test. Penggunaan statistik mensyaratkan bahwa data setiap variabel yang akan dianalisis harus berdistribusi normal dan homogen. Oleh karena itu dilakukan pengujian normalitas data dan pengujian homogenitas data. t-test dimaksudkan untuk menguji hipotesis penelitian tentang implementasi teknik pengelolaan diri untuk meningkatkan kedisiplinan siswa di SMA Negeri 3 Pangkep Kabupetn Pangkep.

\section{Hasil Dan Pembahasan}

Hasil penelitian yang dilakukan terhadap 30 orang siswa mengenai implementasi teknik pengelolaan diri untuk meningkatkan kedisiplinan siswa di SMA Negeri 3 Pangkep Kabupetn Pangkep. Data diperoleh melalui instrumen berupa angket tingkat kedisiplinan siswa untuk mengukur keberhasilan pelaksanaan implementasi teknik pengelolaan diri untuk meningkatkan kedisiplinan siswa. Pelaksanaan penelitian ini dilakukan mulai pada bulan Mei sampai dengan Bulan September 2019. Adapun hasil penelitian ini diuraikan sebagai berikut:

1. Tingkat Kedisiplinan Siswa

Data hasil angket pretest dan posttest dianalisis dengan analisis data statstik untuk mengetahui gambaran tingkat kedisiplinan siswa yang dapat dilihat pada tabel berikut ini:

Tabel 1: Persentase Distribusi Data Frekuensi

\begin{tabular}{clcccc}
\hline \multirow{2}{*}{ Interval } & \multirow{2}{*}{ Kategori } & \multicolumn{2}{c}{ Preetest } & \multicolumn{2}{c}{ Posttest } \\
\cline { 3 - 6 } & & $f$ & $\%$ & $f$ & $\%$ \\
\hline $108-128$ & Sangat tinggi & 0 & $0 \%$ & 6 & $20 \%$ \\
$89-107$ & Tinggi & 0 & $0 \%$ & 21 & $70 \%$ \\
$70-88$ & Sedang & 9 & $30 \%$ & 3 & $10 \%$ \\
$51-69$ & Rendah & 18 & $60 \%$ & 0 & $0 \%$ \\
$32-50$ & Sangat rendah & 3 & $10 \%$ & 0 & $0 \%$
\end{tabular}




\begin{tabular}{lllll} 
Jumlah & 30 & $100,00 \%$ & 30 & $100,00 \%$ \\
\hline
\end{tabular}

Dari data distribusi frekuensi hasil angket preetest, dapat dilihat bahwa tingkat kedisiplinan pada kategori sangat tinggi dan tinggi tidak ada $(0 \%)$, selanjutnya tingkat kedisiplinan siswa yang berada pada kategori sedang terdapat 9 orang $(30 \%)$, lalu tingkat kedisiplinan siswa yang berada pada kategori rendah sebanyak 18 orang $(60 \%)$, dan tingkat kedisiplinan siswa berada pada kategori sangat rendah sebanyak 3 orang $(10 \%)$. Dari hasil persentase tabulasi angket dapat digolongkan bahwa tingkat kedisiplinan siswa tergolong dalam kategori rendah.

Selain itu data tersebut juga diperkuat dengan melihat nilai rata-rata (mean) hasil pretest tingkat kedisiplinan siswa yakni sebesar 65,3 jika dikonversi dengan interval berarti berada pada kategori rendah. Berdasarkan persentase tersebut maka dapat di simpulkan bahwa tingkat kedisiplinan siswa sebelum diberikan perlakuan berupa teknik pengelolaan diri berada pada kategori rendah.

Selanjutnya dari tabel data frekuensi angket posttest, dapat dilihat bahwa tingkat kedisiplinan siswa yang memperoleh skor angket pada kategori sangat tinggi sebanyak 6 orang $(20 \%)$. Selanjutnya tingkat kedisiplinan siswa yang berada pada kategori tinggi sebanyak 21 orang $(70 \%)$. Kemudian tingkat kedisiplinan siswa yang berada pada kategori sedang sebanyak 3 orang $(10 \%)$, serta tidak terdapat siswa yang berada pada kategori rendah dan sangat rendah.

Selain itu data tersebut juga diperkuat dengan melihat nilai rata-rata (mean) hasil postest tingkat kedisiplinan siswa yakni sebesar 98 jika dikonversi dengan interval berarti berada pada kategori tinggi. Berdasarkan persentase tersebut maka dapat di simpulkan bahwa tingkat kedisiplinan siswa setelah diberikan perlakuan berupa teknik pengelolaan diri berada pada kategori tinggi.

2. Implementasi Teknik Pengelolaan Diri Untuk Meningkatkan Kedisiplinan Siswa

Pengujian hipotesis dalam penelitian ini untuk mengungkap efektivitas teknik pengelolaan diri untuk meningkatkan kedisiplinan siswa di SMA Negeri 3 Pangkep, sebelum mengetahui pengaruh tersebut maka harus diubah hipotesisnya menjadi hipotesis kerja yaitu: "teknik pengelolaan diri tidak dapat meningkat kedisipilan siswa di SMA Negeri 3 Pangkep. Adapun kriteria pengujiannya adalah Tolak Ho jika jika $P_{\text {hitung }} \leq 0,05$.

Berdasarkan data empirik hasil analisis statistik menunjukkan perolehan nilai adalah 0.000 $(0.000<0.05)$ (terlampir). Berdasarkan uji hipotesis ternyata hipotesis nihil (Ho) dinyatakan ditolak dan konsekuensinya hipotesis kerja ( $\mathrm{Ha}$ ) diterima, maka dapat disimpulkan bahwa teknik pengelolaan diri efektiv untuk meningkat kedisipilan siswa di SMA Negeri 3 Pangkep.

Selain uji hipotesis tersebut, evektivitas teknik pengelolaan diri untuk meningkat kedisipilan siswa di SMA Negeri 3 Pangkep, juga dapat dilihat dari perbedaan nilai rata-rata (mean) pada nilai pretest dengan nilai postest, pada pretest nilai mean sebesar 65,3 sedangkan pada postest nilai mean sebesar 98 , sehingga nilai mean kedua data tersebut dapat dilihat perbedaan yang signifikan.

Berdasarkan uraian tersebut, dapat disimpulkan bahwa teknik pengelolaan diri dapat meningkat kedisipilan siswa di SMA Negeri 3 Pangkep, artinya semakin diberi teknik pengelolaan diri, maka akan diikuti dengan meningkatnya kedisiplinan pada siswa.

\section{Pembahasan}

Istilah disiplin seringkali dikaitkan dengan istilah tata tertib dan peraturan, hal tersebut dikarenakan disiplin dapat dimaknai sebagai suatu kondisi yang tercipta melalui serangkaian perilaku yang didorong keinginan dalam diri untuk menunjukkan ketaatan, kepatuhan, kesetiaan, keteraturan atau ketertiban. Disiplin terbentuk sejak anak berada dalam lingkungan keluarga, lalu berkembang di sekolah dan masyarakat. Penanaman disiplin tersebut dimaksudkan agar seseorang dapat menyesuaikan diri dengan cara menaati tata tertib yang berlaku. Disiplin diperlukan agar seseorang dapat bahagia dan menjadi orang yang berhasil dalam penyesuaiaan dirinya. Melalui perilaku disiplin individu dapat belajar berperilaku dengan cara yang diterima oleh masyarakat dan tata tertib yang berlaku.

Berdasarkan uraian diatas dapat dipahami bahwa dengan adanya disiplin maka perilaku seseorang akan tertata dan terarah sehingga mampu beradaptasi dengan baik dan positif terhadap lingkungan. Dampak perilaku disiplin tersebut akan berpengaruh terhadap disiplin dalam belajar, sehingga dapat diharapkan pada keberhasilan belajar yang optimal. 
Kegiatan pembelajaran di sekolah tidak hanya mengembangkan kemampuan aspek kognitif, namun juga aspek afektif dan psikomotorik siswa, artinya sekolah memiliki tujuan mencetak siswa yang berprestasi secara akademik, memiliki sikap dan kepribadian yang unggul. Untuk mewujudkan tujuan sekolah tersebut maka diperlukan suatu kondisi yang mampu membentuk dan mengendalikan pola perilaku siswa sesuai tata tertib yaitu disiplin.

Gambaran tingkat keisiplinan siswa dapat dilihat berdasarkan hasil penelitian. Berdasarkan hasil penelitian di lapangan dapat di simpulkan bahwa tingkat kedisiplinan siswa sebelum diberikan perlakuan berupa teknik pengelolaan diri berada pada kategori rendah. Selanjutnya tingkat kedisiplinan siswa setelah diberikan perlakuan berupa teknik pengelolaan diri berada pada kategori tinggi.

Gunarsa (Nurzakiyah dan Budiman, 2015 :14) menyatakan bahwa "Self-management merupakan salah satu model dalam cognitive-behavior therapy. Self-management meliputi pemantauan diri (self-monitoring), reinforcement yang positif (self-reward), kontrak atau perjanjian dengan diri sendiri (self-contracting), dan penguasaan terhadap ransangan (stimulus control).

Anggapan dasar Self management merupakan teknik kognitif behavioral adalah bahwa setiap perilaku manusia itu merupakan hasil dari proses belajar (pengalaman) dalam merespon berbagai stimulus dari lingkungannya. Namun self managemet juga menolak pandangan behavioral radikal yang mengatakan bahwa manusia itu sepenuhnya dibentuk dan ditentukan oleh lingkungannya. $\mathrm{Hal}$ ini dikarenakan self-management memandang klien memiliki kemampuan untuk mengamati, mencatat dan menilai pikiran, perasaan, dan tindakannya sendiri. Pada dasarnya klien memiliki kekuatan dan keterampilan yang dapat dikembangkan untuk menyeleksi faktor-faktor lingkungan dan penyerahan tanggung jawab kepada klien untuk mengubah perilaku karena klienlah yang paling tahu, paling bertanggung jawab, dan dengan demikian paling mungkin untuk mengubah dirinya. Ikhtiar mengubah atau mengembangkan diri atas dasar inisiatif dan penemuan sendiri, membuat perubahan itu bertahan lama.

Self-Management merupakan salah satu teknik dalam konseling kelompok yang berupa pengarahan diri sendiri untuk mengubah perilaku sesuai yang diharapkan. Nursalim (2013: 149), menyatakan: Self-Management adalah suatu proses dimana konseli mengarahkan perubahan tingkah laku mereka sendiri, dengan menggunakan satu strategi atau kombinasi strategill. Stewart dan Lewis (Nursalim, 2013: 150) menyatakan dalam bidang konseling, Self-Management (SM) merupakan suatu prosedur yang baru. Self-Management, kadang-kadang disebut behavioral selfcontrol, menunjuk pada kemampuan individu untuk mengarahkan perilakunya, yaitu kemampuan untuk melakukan hal-hal yang terarah bahkan meskipun upaya-upaya tersebut sulit.

Pendapat tersebut dapat dimaknai bahwa self-management merupakan terapi yang membantu konseli mengubah dan mengontol tingkah laku yang lebih efektif untuk pencapain suatu tujuan tertentu. Soekardji (Nursalim, 2013 :151) menyatakan: Self-Management ialah prosedur dimana seseorang mengarahkan atau mengatur tingkah lakunya sendiri. Pada prosedur ini biasanya subjek terlibat pada lima komponen dasar yaitu: menentukan perilaku sasaran, memonitor perilaku tersebur, memilih prosedur yang akan diterapkan, melaksanakan prosedur tersebut dan mengevakuasi efektivitas prosedur tersebut.

Penerapan teknik selfmanagement dengan mengkombinasikan teknik lebih efektif dari pada menggunakan satu teknik saja. Menurut Sugiharto (Handoko, 2014: 6) ada tiga teknik yang fisibel untuk diterapkan dalam melakukan strategi pengelolaan diri, yaitu: pantau diri (self-monitoring), kendali stimulus (stimulus control), dan ganjar diri (self-reward).

Berdasarkan pendapat tersebut dapat dimaknai bahwa self-management merupakan suatu prosedur baru dalam konseling yang menunjuk pada kemampuan individu untuk memonitor diri, mengarahkan perilaku dan memberikan hadiah pada diri sendiri apabila berperilaku sesuai yang diharapkan.

Nursalim (2013: 149) mengemukakan ada tiga macam strategi self management yaitu: selfmonitoring, stimulus-contro dan self-reward. Self-monitoring adalah upaya konseli untuk mengamati diri sendiri, mencatat sendiri tingkah laku tertentu (pikiran, perasaan dan tindakan) tentang dirinya dan interaksinya dengan peristiwa lingkungan. Self-monitoring merupakan suatu proses konseli mengamati dan mencatat segala sesuatu tentang dirinya sendiri dalam interaksinya dengan lingkungan. Strategi pemantauan diri ini konseli mengamati dan mencatat perilaku tidak 
disiplin yang dilakukan, mengendalikan penyebab terjadinya masalah tidak disiplin (antecedent) dan menghasilkan konsekuensi apabila perilaku tidak disiplin tersebut dilakukan kembali.

Stimulus-control adalah merancang sebelumnya antecedent atau syarat pedoman atau petunjuk untuk menambah atau mengurangi tingkah laku. Strategi stimulus-control dilakukan dengan memodifikasi lingkungan agar dapat mendukung terciptanya perilaku disiplin terhadap tata tertib sekolah.

Self-reward adalah pemberian hadiah pada diri sendiri, setelah tercapainya tujuan yang diinginkan. Self-reward dilakukan setelah konseli berhasil berperilaku disiplin terhadap tata tertib sekolah sebagai indikator tercapainya tujuan self-management. Konseli berhak memberikan dan menentukan sendiri self-reward yang diinginkan.

Nursalim (2013: 149) mengemukakan aspek-aspek strategi self-management yaitu 1) Konseli dilatih pengarahan diri dalam interview, 2) Konseli mengarahkan diri sendiri melalui tugas pekerjaan rumah, 3) Konseli mengamati sendiri dan mencatat sendiri tingkah laku yang diinginkan atau pekerjaan rumah, 4) Menghadiahi diri sendiri setelah keberhasilan tingkah laku tindakannya dan tugas rumah.

Pendapat tersebut dapat dimaknai bahwa strategi self-management memerlukan kesadaran diri untuk melakukan pengarahan diri untuk pengubahan tingkah laku yang diinginkan melalui penyelesaian tugas maupun pekerjaan rumah.

Selanjutnya berdasarkan hasil uji hipotesis penelitian dapat dinyatakan bahwa teknik pengelolaan diri dapat meningkat kedisipilan siswa di SMA Negeri 2 Pangkep, artinya semakin diberi teknik pengelolaan diri, maka akan diikuti dengan meningkatnya kedisiplinan pada siswa.

\section{Kesimpulan Dan Saran}

Berdasarkan hasil penelitian dan pembahasan yang dilakukan, maka diperoleh kesimpulan dalam penelitian ini bahwa gambaran tingkat kedisiplinan siswa sebelum diberikan perlakuan berupa teknik pengelolaan diri berada pada kategori rendah, selanjutnya tingkat kedisiplinan siswa setelah diberikan perlakuan berupa teknik pengelolaan diri berada pada kategori tinggi.

Selain itu berdasarkan hasil uji hipotesis penelitian dapat simpulkan bahwa ada pengaruh strategi implementasi teknik pengelolaan diri untuk meningkatkan kedisiplinan siswa di SMA Negeri 3 Pangkep, artinya melalui implementasi teknik pengelolaan diri, maka kedisiplinan siswa akan bertambah atau meningkat.

Berdasarkan kesimpulan yang di atas, maka disarankan: (1) Bagi guru guru bimbingan dan konseling di sekolah agar mengimplementasikan teknik pengelolaan diri untuk meningkatkan kedisiplinan siswa di sekolah; (2) Bagi Siswa diharapkan agar dapat meningkatkan kemampuan bimbingan keterampilan sosial mereka masing-masing.

\section{Daftar Rujukan}

Elly. 2016. Hubungan Kedisiplinan Terhadap Hasil Belajar Siswa Kelas V DI SD Negeri 10 Banda Aceh. JURNAL PESONA DASAR Vol. 3 No.4, Oktober 2016, hal. 43-53 ISSN: 2337-9227.

Fiana. 2013. Disiplin Siswa di Sekolah dan Implikasinya dalam Pelayanan Bimbingan dan Konseling. Konselor. Jurnal Ilmiah Konseling. Volume 2 Nomor 23 April 2013.

Fajriani. 2016. Self-Management Untuk Meningkatkan Kedisiplinan Belajar Siswa: Studi Kasus Di SMA Negeri 5 Banda Aceh. Jurnal Pencerahan Volume 10, Nomor 2, September 2016 Halaman: 95102 ISSN: $1693-1775$

Haryono. 2016. Pengaruh Kedisiplinan Siswa Dan Motivasi Belajar Terhadap Prestasi Belajar Siswa Pada Mata Pelajaran Ekonomi. Faktor Jurnal Ilmiah Kependidikan Vol. 3 No. 3 November 2016, hal 261-274.

Handoko, T. Hani, 2014. Manajemen Personalia Sumber Daya Manusia, Edisi. Kedua. Yogyakart: BPFE. 
KONSELING: Jurnal Ilmiah Bimbingan dan Konseling

Vol.1, No.1, Oktober 2019

Available online: https://journal.ilininstitute.com/konseling

Hasbahuddin, Rosmawati

Isnaini, F. \& Taupik. 2015. Strategi Self-Managemen Untuk Meningkatkan Kedisiplinan Belajar. Jurnal Penelitian Humaniora, Vol. 16, No. 2, Agustus 2015: 33-4234

Komalasari. 2011. Pembelajaran Kontekstual. Bandung: Refika Aditama.

Komalasari. 2011. Teori dan Teknik Konseling. Jakarta: PT. Indeks.

Nursalim, M. 2013. Pengembangan Media Bimbingan dan Konseling. Jakarta: Indeks.

Nuryasih. 2017. Konseling Kelompok Dengan Strategi Pengelolaan Diri Untuk Meningkatkan Disiplin Belajar Siswa Kelas IV SDN 1 Triwarno. Jurnal Kalam Cendekia Pgsd Kebumen Vol 5, No 5 (2017)

Nurzakiyah, Siti \& Nandang Budiman. 2015. Teknik Self-Management Dalam Mereduksi Body Dysmorphic Disorder.

Slameto. 2010. Belajar dan Faktor-faktor yang Mempengaruhi. Jakarta: Rieneka Cipta.

Sa'diyah. 2016. Penerapan Teknik Self Management Untuk Mereduksi Agresifitas Remaja. Jurnal Ilmiah Counsellia, Volume 6 No. 2, November 2016: 67 - 78

Wibowo. 2012. Manajemen Kinerja. Jakarta: Raja Grafindo Perkasa. 